\title{
PERAN BAWASLU KOTA BANDAR LAMPUNG DALAM PENANGANAN PELANGGARAN ADMINISTRATIF CALEG PARTAI AMANAT NASIONAL (PAN) DAPIL IV KOTA BANDAR LAMPUNG TAHUN 2019
}

\author{
Yonnawati $^{1}$, Tia Marlinda ${ }^{2}$ \\ Yonawati224@gmail.com, tiamarlinda22@gmail.com

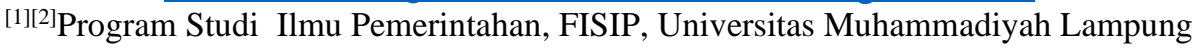

\begin{abstract}
ABSTRAK
Penelitian ini dilakukan untuk menjelaskan peran Bawaslu kota Bandar Lampung dalam penanganan pelanggaran yang terjadi saat pemilu khususnya pelanggaran administratif yang melibatkan salah satu caleg dari Partai Amanat Naional atas Nama H. Erwansyah calon anggota DPRD Dapil IV Kota Bandar Lampung penelitian ini bertujuan agar mengetahui Peran Bawaslu kota Bandar Lampung dalam penegakan Hukum penanganan pelaggaran adminitratif Caleg PAN Dapil IV pada pemilu tahun 2019 kota Bandar Lampung. Mengetahui strategi yang dilakukan Bawaslu Kota Bandar Lampung untuk mengoptimalkan perannya dalam penegakan Hukum penanganan pelanggaran administratif Caleg PAN Dapil IV pada pemilu tahun 2019 Kota Bandar Lampung. Penelitian ini menggunakan metode penelitian kualitatif. Hasil penelitian menunjukan bahwa peran Bawaslu kota Bandar Lampung dalam penanganan pelanggaran administratif partai amanat nasional (PAN) dapil IV Kota Bandar Lampung berdasarkan Perbawaslu 7 dan 8 Tahun 2018 dengan penerimaan laporan, pengumpulan alat bukti, klarifikasi, serta penerusan hasil kajian kepada instansi yang berwenang, pengkajian dan pemberian rekomendasi serta membuat strategi dengan cara penguatan kapasitas, melakukan pembinaan dan membentuk pola komunikasi antar instansi terkait mapun penguatan fungsi akomodasi dan tata kelola sudah berjalan dengan baik atau maksimal.
\end{abstract}

Kata Kunci: Bawaslu, Pelanggaran Administratif, Partai Amanat Nasional (PAN)

\section{PENDAHULUAN}

Pemilihan umum merupakan salah satu tolak ukur stabilitas demokratisasi suatu negara. Hakikatnya pelaksanaan pemilu di Indonesia merupakan sarana pemenuhan demokrasi dari suatu negara, yang berdasarkan atas kedaulatan rakyat yang sesuai dengan pasal 1 ayat (2) UUD Negara Republik Indonesia tahun 1945 yang menjelaskan bahwa kedaulatan berada ditangan rakyat. Penyelenggara pemilu adalah lembaga yang meyelenggarakan pemilu yang terdiri dari Komisi Pemilihan Umum dan Dewan Kehormatan Penyelenggara Pemilu untuk memilih anggota Dewan Perwakilan Rakyat, Dewan Perwakilan Daerah, Dewan Perwakilan rakyat Daerah, Presiden dan Wakil Presiden secara langsung oleh rakyat, serta untuk memilih Gubernur, Bupati dan Walikota secara demokratis. Pada dasarnya Indonesia dibangun atas praktik dan prisip-prinsip tata 


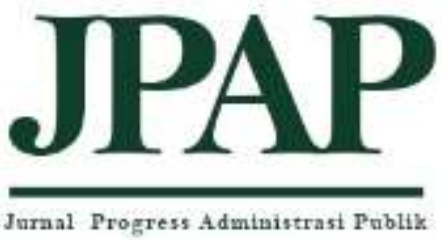

Volume 1 Nomor 2
Pemerintahan yang baik, yakni dengan mewujudkannya pemilihan umum (pemilu) secara jujur dan adil, serta langsung, umum, jujur, dan rahasia. Tetapi masih banyak terjadi masalah dalam system pileg 2019 dalam hal ini peran Bawaslu sangat diperlukan dalam pencegahan dan penindakan di wilayah kabupaten/kota sesuai yang tertera di pasal 101 UU Nomor 7 Tahun 2017 tentang pemilu.

Seperti yang terjadi di pileg 2019 di kota Bandar lampung adanya dugaan pelanggaran administratif yang dilakukan salah satu caleg dari Partai Amanat Nasional atas Nama $H$. Erwansyah calon anggota DPRD Dapil IV kota bandar lampung memperkenalkan diri sebagai calon anggota DPRD kota bandar lampung pada acara arisan PKK RT 12 dan memeberikan kuis kepada peserta arisan dengan hadiah berupa uang $\mathrm{Rp}$. 50.000 bagi ketiga orang pemenang kuis yang diberikan berupa pertanyaan bagaimana mencoblos dengan baik dan benar dan mebmbagikan bahan kampanye kepada peserta arisan berupa mug pada kegiatan kampanye tersebut diketahui tidak menggunakan STTP (surat tanda terima pemberitahuan) kampanye, ini sudah menyalahi aturan atau SOP (Standar Operating Procedure) yang dimana yang disebutkan di dalam PKPU (Peratuan KPU) Nomor 33 Tahun 2018, tentang kampanye pemilihan umum, terdapat ketentuan tentang pertemuan terbatas.
Begitu pula di pasal 29 tentang aturan kampanye pertemuan tatap muka dan pasal 43 tentang atauran kampanye rapat umum yang wajib menyampaikan pemberitahuan tertulis. Dugaan pelanggaran ini dijadikan pelanggaran admiistratif pemilu TSM (tersturktur, sistematis, dan masif) dan paling lama ditetapkan nya ini tujuh hari sejak ditemukan dugaan pelanggaran.

Adapun laporan yang dibuat ini untuk memutuskan pelanggaran admistratif ini harus mempunyai bukti yang sah, ada beberapa alat bukti yang yaitu berupa keterangan saksi, surat atau tulisan, dugaan pelanggaran admistratif pemilu seperti dugaan yang di temukan oleh panwaslu kecamatan tanjung senang dugaan pelanggaran yaitu kegiatan kampanye yang tidak menggunakan STTP (surat tanda terima pemberitahuan) kampanye yang ditemukan di Kecamatan Tanjung Senang laporan ini dilaporkan oleh ketua panwaslu kecamatan tanjung senang atas nama Hobi Harta dengan nomor register No.001TM/PL/ADM/Kot/08.01/XII/2018 yang di peroleh dari Bawaslu kota Bandar Lampung setelahnya baru laporan ini bisa dilanjutkan ketahap pemeriksaan pendahuluan yaitu pemerikasaan bukti dan kedudukan terlapor dan pelapor. Sidang pemeriksaan pertama memanggil lewat surat pemberitahuan sidang memanggil pelapor, terlapor dan saksi disertai dengan dokumen laporan dugaan pelanggaran admistratif pemilu dan di edarkan 1 hari sebelum sidang pemeriksaan disana juga semua macam bukti di paparkan mulai dari 


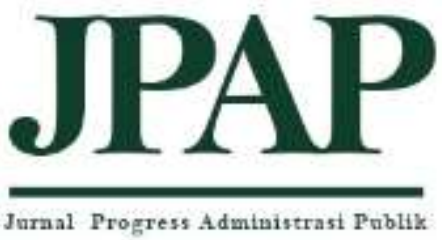

Volume 1 Nomor 2

keterangan saksi, surat atau tulisan, petunjuk, dokumen elektronik maupun keterangan ahli dan setelahnya bawaslu baru bisa memutuskan laporan dugaan pelanggaran administratif pemilu dengan mempertimbangkan alat bukti yang dikemukakan dalam pemeriksaan dan putusan bawaslu diputuskan dalam rapat pleno pengambilan keputusan yang bersifat tertutup dan dibacakan dalam sidang bersifat terbuka untuk umum pada kasus yang ada di temukan oleh panwaslu tanjung senang maka Bawaslu Kota Bandar Lampung memutuskan kasus ini di terima dan amar keputusan nya.

1. Menyatakan terlapor terbukti secara sah dan meyakinkan melakukan pelanggaran terhadap tata cara, prosedur atau mekanisme yang berkaitan dengan adminitrasi pelaksanaan pemilu.

2. Memerintahkan kepada KPU Kota Bandar Lampung memberikan teguran tertulis kepeda calon anggota DPRD Kota Bandar Lampung dapi IV (empat) dari Partai Amanat Nasional Nomor urut 5 (lima) atas nama $\mathrm{H}$. Erwansyah sesuai dengan peraturan perundang-undangan yang berlaku.

\section{METODE}

Penelitian ini menggunakan penelitian kualitatif. Menurut Husaini Usman (2009:78) metode kualitatif lebih berdasarkan pada filsafat fenomenologis yang mengutamakan penghayatan (verstehen). Metode kualitatif berusaha memahami dan menafsirkan makna suatu peristiwa interaksi tingkah laku manusia dalam situasi teetentu menurut perspektif peneliti sendiri. Resfonden dalam metode kualitatif berkembang terus (snowball) secara bertujuan (purposive) sampai data yang dikumpulkan. Alat pengumpul data atau instrumen penelitian dalam metode kualitatif adalah peneliti sendiri. Jadi, peneliti merupakan key instrument, dalam mengumpulkan data, peneliti harus melihat sendiri ke lapangan secara aktif.

\section{ANALISIS HASIL DAN PEMBAHASAN}

Teori Keuangan Desa. Keuangan berasal dari terjemahan kata monetary atau moneter, sedangkan kata finance mempunyai arti pembiayaan. Hasil observasi penelitian bahwa Pada hari Jum'at tangal 7 Desember 2018 pukul 15:00 WIB Ketua Panwaslu Kecamatan Tanjung Senang Hobi Harta mendapatkan informasi awal dugaan Pelanggaran Administratif Pemilu berupa foto kegiatan Arisan ibu-ibu PKK Rt 12 yang dihadiri oleh Calon Anggota DPRD Kota Bandar Lampung Dapil IV Kota Bandar Lampung Nomor Urut 5 Partai Amanat Nasional (PAN) atas nama H. Erwansyah di Jl. Raja Tihang, Gg Mangga 2, No 00, RT 12, LK 1, Kelurahan Tanjung Senang, Kecamatan Tanjung Senang Kota Bandar Lampung. Pada tanggal 1 Desember 2018 Calon Anggota DPRD Kota Bandar Lampung Dapil IV Kota Bandar Lampung Nomor Urut 5 Partai Amanat Nasional (PAN) atas nama H. Erwansyah memperkenalkan diri sebagai Calon 


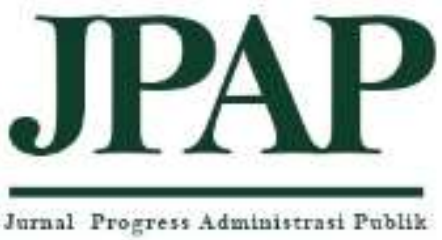

Jural Progress Administrast Publi

Volume 1 Nomor 2

Anggota DPRD Kota Bandar Lampung Dapil IV Nomor urut 5 Partai Amanat Nasional (PAN) atas nama $H$. Erwansyah pada acara arisan PKK RT 12 dan memberikan kuis kepada peserta arisan dengan hadiah berupa uang senilai Rp.50.000 bagi ketiga orang pemenang. Kuis yang diberikan berupa pertanyaan bagaimana mencoblos dengan baik dan benar dan membagikan bahan kampanye kepada peserta arisan berupa mug. Pada kegiatan kampanye tersebut diketahui tidak menggunakan STTP (Surat Tanda Terima Pemberitahuan) dan diduga membagikan uang kepada peserta arisan.

Pada hari Rabu tanggal 12 Desember 2018 Ketua Panwaslu Kecamatan Tanjung Senang melakukan Investigasi kepada Rosmaida dan Nurlaila dari keterangan yang didapat oleh Ketua Panwaslu Kecamatan Tanjung Senang bahwa benar Calon Anggota DPRD Kota Bandar Lampung Dapil IV Kota Bandar Lampung Nomor urut 5 Partai Amanat Nasional (PAN) atas nama $H$. Erwansyah hadir pada acara arisan ibuibu PKK RT 12 dan memperkenalkan diri sebagai Calon Anggota DPRD Kota Bandar Lampung Dapil IV Kota Bandar Lampung Nomor 5 Partai Amanat Nasional (PAN) serta memberi kuis mengenai tata cara Pencoblosan yang baik dan benar kepada peserta arisab ibu-ibu PKK dan bagi ketiga pemenang diberi hadiah sebesar Rp.50.000, maka dari itu Panwaslu Kecamatan Tanjung Senang melakukan kajian awal terhadap dugaan yang dilakukan oleh Calon
Anggota DPRD Kota Bandar Lampung Dapil IV Kota Bandar Lampung Nomor urut 5 Partai Amanat Nasional (PAN) atas nama $\mathrm{H}$. Erwansyah.

Teguran tertulis Komisi Pemilihan Umum (KPU) Kota Bandar Lampung. Prosedur dan mekanisme yang Berdasarkan Putusan Bawaslu Kota Bandar Lampung Nomor: 001 / TM / ADM / Kot / 08.01 / XXI/2018, Pelanggaran sebagaimana dimaksud diatas merupakan Pelanggaran Administratif Pemilu merupakan perbuatan atau tindakan yang melanggar tata cara berkaitan dengan administrasi pelaksanaan pemilu dan terlapor terbukti secara sah dan menyakinkan melakukan pelanggaran tersebut. Berdasarkan faktafakta yang terungkap dalam sidang Pemeriksaan yang dilakukan oleh Bawaslu Kota Bandar Lampung, bahwa terlapor hadir dalam acara arisan RT 12 Kelurahan Tanjung Senang. Terlapor memperkenalkan diri dan memberikan arahan bertujuan untuk memberikan informasi mengenai cara mencoblos yang baik dan benar, kemudian diarahkan untuk mengambil kertas berwarna hijau dan mencari Partai Amanat Nasional dan Nomor 5 atas nama Terlapor serta memberikan sejumlah uang kepada peserta arisan yang dapat mengikuti arahannya dengan benar dan membagikan bahan kampanye berlogo Partai dan Calon Anggota DPRD atasnama Terlapor. Dalam melakukan kegiatan tersebut berdasarkan regulasi dalam peraturan Komisi 


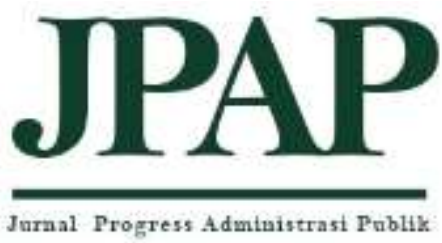

Volume 1 Nomor 2
Pemilihan Umum Nomor 23 tahun 2018 tentang Kampanye pemilu yang terakhir diperbaharui dengan peraturan Komisi Pemilihan Umum Nomor 33 Tahun 2018 menyatakan bahwa setiap kegiatan kampanye wajib menyampaikan atau membuat STTP kampanye dari kepolisian dan ditembuskan ke Bawaslu dan KPU sebagaimana diatur dalam Pasal 27 dan 28 tentang pertemuan terbatas termasuk pertemuan tatap muka. Berdasarkan hal tersebut diatas, terdapat pelanggaraan administrasi Pemilu yang selanjutnya diteruskan kepada Komisi Pemilihan Umum Kota Bandar Lampung untuk ditindaklanjuti sesuai dengan ketentuan yang berlaku. Sesuai dengan Hasil Putusan Bawaslu tersebut Komisi Pemilihan Umum Kota Bandar lampung memberikan Sanksi berupa teguran Tertulis melalui Surat.

\section{PENUTUP}

Berdasarkan hasil pembahasan dan serangkaian analisis ini maka disimpulkan bahwa:

a. Bawaslu Kota Bandar Lampung sebelumnya disosialisasi sudah memberitahukan tentang peraturan apa saja yang seharusnya dilakukan saat masa kampanye termasuk tentang STTP (surat tanda terima pemberitahuan) kampanye yang sudah tertuang di dalam pasal 43 PKPU (praturan KPU) Nomor 33 tahun 2018 yang tentang aturan kampanye rapat umum yang wajib menyampaikan pemberitahuan tertulis tetapi caleg PAN atas nama H.Erwansyah dengan alasan lupa untuk membuat surat tersebut.

b. Bawaslu Kota Bandar Lampung dalam hal proses penanganan pelanggaran administratif caleg PAN Dapil IV Nomor urut 5 kota Bandar Lampung telah dilakukan sesuai perundang-undangan berpedoman pada Undang-Undang Nomor 7 Tahun 2017, Perbawaslu 7 dan 8 Tahun 2018 yaitu meliputi dengan menerima laporan, mengumpulkan alat bukti, serta penerusan hasil kajian kepada instansi yang berwenang dengan mengkaji terlebih dalulu dan memberikan pemberitahuan rekomendasi.

\section{REFERENSI}

Abdullah, Rozali. 2009. Mewujudkan Pemilu Yang Lebih Berkualitas. Jakarta: Raja grafindo Persada.

Bungin, Burhan. 2012. Penelitian Kualitatif Komunokasi, Ekonomi, Kebijakan Politik, Kebijakan Publik dan Ilmu Sosial Lainnya. Jakarta: Kencana.

Haryanto. 2009. Partai Politik Suatu Tinjauan Umum. Yogyakarta: Liberty.

Husein, Harun. 2014. Pemilu Indonesia; Fakta, Angka, Analisis dan Studi Banding. Jakarta: Perludem.

Labolo, Muhadam dan Ilham, Teguh. 2015. Partai Politik Dan Sistem 
Pemilihan Umum Di Indonesia.

Depok: Rajagrafindo Persada.

Morisan, M. A. 2010. Management

Public Relations. Jakarta:

Kencana Prenada Media Group.

S. Tangkilisan, Hessel Nogi. 2009. Manajemen Publik. Jakarta: PT

Gramedia Widiasarana Indonesia.

Santoso, Topo. 2009. Tindak Pidana

Pemilu. Jakarta: Sinar Grafika.

Surwantoro, Gunawan. 2016. Mengawal

Penegak Demokrasi Di Balik

Tata Kelola Bawaslu Dan DKPP.

Jakarta: Erlangga.

Usman, Husaini dan Setiady, Purnomo. 2009. Metode Penelitian Sosial. Jakarta: Bumi Aksara.

Jurnal:

Ansori. 2017. Legalitas Hukum Komisi Pemilihan Umum Daerah Dalam Menyelenggarakan Pilkada The Legality of Regional Election Regional Head Election. Jurnal Konstitusi 